\title{
GLACIAL DISPERSION STUDY OF KIMBERLITIC MATERIAL IN QUATERNARY TILL FROM THE LAHTOJOKI PIPE, EASTERN FINLAND
}

\author{
Marja Lehtonen and Jukka Marmo \\ Geological Survey of Finland, Espoo, Finland
}

\section{ABSTRACT}

In 2001-2002 the Geological Survey of Finland (GTK) carried out sampling of Quaternary till around the Lahtojoki kimberlite (Pipe 7) in eastern Finland. The objective was to study the mineralogical and geochemical signatures of the kimberlite in the surrounding basal till. Pipe 7 belongs to the Kaavi cluster of the Neoproterozoic Eastern Finland Kimberlite Province situated at the edge of the Karelian Craton. It has mineralogy typical of Group I kimberlite. The 2-ha pipe is located in a swamp and covered by thick glacial overburden. The $2 \times 2.5 \mathrm{~km}$ sampling area was situated down-ice from Pipe 7, samples being taken by an excavator and a drill rig. The concentration of indicator grains $(0.25-1.0 \mathrm{~mm})$ was based on a GTK modified 3"Knelson Concentrator. Chemical analysis of the till fine fraction $(<0.063 \mathrm{~mm})$ was performed using XRF and ICP-MS instruments. The indicator grains form a relatively well-defined fan in the basal till that can be followed at least $2 \mathrm{~km}$ down-ice from the pipe. The maximum concentration of indicators is found at $1.2 \mathrm{~km}$ distance. Another small kimberlitic body was discovered by drilling $300 \mathrm{~m}$ down-ice from the pipe. The indicator population in till corresponds to that of the pipe in grain size, mineralogy and texture. All till samples turned out to be uniform in their chemical composition; no obvious correlation was found between fine fraction geochemistry and indicator content.

\section{INTRODUCTION}

The basic exploration method in glaciated terrains for diamond host rocks, kimberlites and lamproites, particularly during regional work, is to track high pressure and temperature xenocrysts, i.e. ,kimberlitic indicator minerals dispersed as heavy mineral grains in Quaternary till and stream sediments. Recently also the use of till geochemistry has become more popular in regional diamond exploration (McClenaghan \& Kjarsgaard 2001) and it is based on the distinct chemistry of kimberlitic rocks, which are enriched, e.g., in incompatible elements. In 2001-2002 the Geological Survey of Finland (GTK) carried out sampling of Quaternary till around the Lahtojoki kimberlite pipe
(Pipe 7) in eastern Finland. The objective was to study the mineralogical and geochemical signatures of the kimberlite in the surrounding basal till. The results of a previous GTK heavy mineral survey conducted in the area in 1994 was also used in this study.

\subsection{PIPE 7}

Pipe 7 belongs to the Kaavi cluster of the Neoproterozoic Eastern Finland Kimberlite Province situated at the edge of the Karelian Craton (Fig. 1).

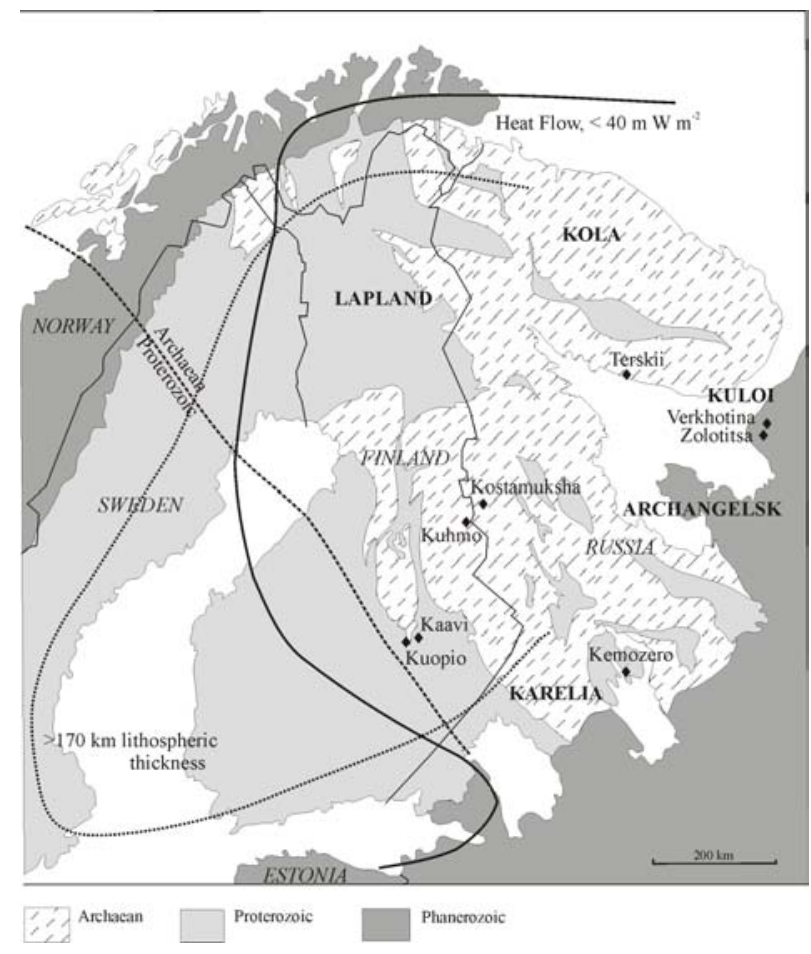

Figure 1: The map presents the diamond prospective area in Northern Europe where there is low heat flow (simplified from Kukkonen \& Jõeleht 1996) and where the lithosphere is thicker than $170 \mathrm{~km}$ based on seismic data (Calcagnile 1982). Generalised geology is modified after Gaál and Gorbatschev (1987). The Archaean/Proterozoic boundary marks the subsurface extent of the Archaean craton. The black diamonds represent diamond-bearing kimberlites and lamproites.

The kimberlites have been emplaced into Archaean (3.1-2.6 Ga) basement gneisses and allochtonous Proterozoic (1.9-1.8 Ga) metasediments thrust onto the craton during the Svecofennian orogeny (Kontinen et al. 1992). The Kaavi cluster, 40 x $20 \mathrm{~km}$ in size, 
comprises at least 11 kimberlites with mineralogy typical of Group I kimberlite including abundant macrocrysts of olivine, picroilmenite, Cr-diopside and pyrope garnet (O'Brien \& Tyni 1999). The accessible part of Pipe 7 is composed of macrocrystal heterolithic kimberlite of the diatreme facies and subordinate hybabyssal facies kimberlite (Peltonen 1999). The indicator minerals in Pipe 7 include picroilmenite, purple G9/G10 Cr-pyrope garnet according to the Dawson \& Stevens bar chart (1975), G1/G2 or G3/G4 orange garnet and $\mathrm{Cr}$-diopside, chromite being virtually absent. Mini-bulk sampling results of the pipe suggest an average of 26 carats $(>0.8 \mathrm{~mm})$ per hundred tons (Tyni 1997). The 2-ha body is suboval in plan, measuring approximately $200 \mathrm{~m}(\mathrm{E}-\mathrm{W}) \times 100 \mathrm{~m}(\mathrm{~N}-\mathrm{S})$ at maximum. It is located in a swamp and covered by 13-20 m glacial overburden.

\subsection{THE QUATERNARY GEOLOGY AND THE BEDROCK IN THE STUDY AREA}

The glacial till and moraine formations in the Kaavi area consist of basal till deposited under an actively flowing glacier (indicated by drumlin fields) and of melt-out till deposited in the cavities under a melting glacier. Both formations date back to the deglaciation at the end of the Weichselian, when large glacial lobes developed in southern and central parts of Finland (Nenonen 1995). The main ice flow direction in the region is $335^{\circ}$ (Hirvas \& Nenonen 1987) that can be observed as striations in polished rock surfaces and as the basal till stone fabric. The basal till is relatively thin, usually $<2 \mathrm{~m}$, and just covers bedrock forms and fills the deepest depressions of the terrain.

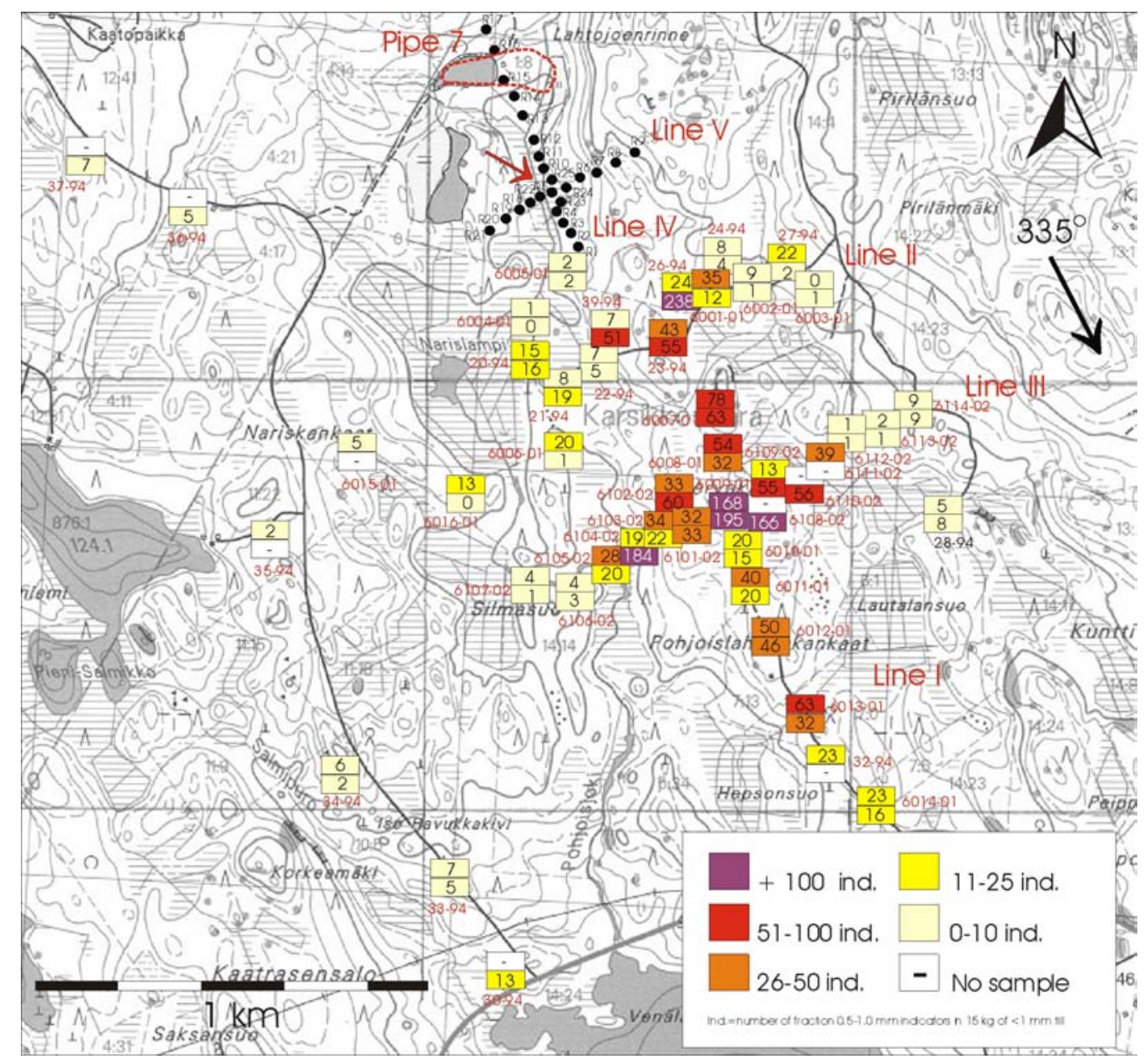

Figure 2: The sampling area down-ice from Pipe 7. The dashed red line marks the borders of Pipe 7. The black arrow indicates the main ice flow direction $\left(335^{\circ}\right)$. The normalised indicator contents of the excavator sampling sites (i.e. the number of $0.5-1.0$ $\mathrm{mm}$ fraction indicators in $15 \mathrm{~kg}$ of $<1 \mathrm{~mm}$ till ) are marked in double boxes. The value in the lower box represents the indicator content at the base of the till bed and the upper value that of the upper till. The drilling profiles are marked with black dots. The red arrow shows the discovery site of the new kimberlitic body. 
The bedrock of the sampling area is mainly composed of 1.9-1.8 Ga allochthonous sequences emplaced onto the craton margin (mica schists, gneisses and intercalated black schists) with intracratonic $2.2 \mathrm{Ga}$ amphibolites as well as post collisional $1.86 \mathrm{Ga}$ intrusion granites and granodiorites (Korsman et al. 1997).

\section{METHODOLOGY}

\subsection{SAMPLING}

The sampling area (Fig. 2) situated down-ice from the kimberlite was approximately $2 \times 2.5 \mathrm{~km}$ in size. In total 46 excavator pits were done and from each 1 to 4 20-kg till samples were taken depending on the thickness of the till bed. The objective of the longest sampling profile (Line 1) parallel to the main ice flow was to define the area of maximum concentration of indicators derived from the pipe and to measure the length of the dispersion fan. Perpendicular profiles (Lines 2 and 3) were done in order to determine the width and spreading angle of the fan. Line 3 was placed at the second sampling stage at the indicator maximum area on Line 1. Some sampling was also done up-ice from the kimberlite to estimate the regional background indicator concentration in the area due to the effect of the other Kaavi cluster kimberlites. In order to study the pipe area covered by thick glacial overburden a drill rig was used for sampling. Twenty-five holes were drilled to form two crossing lines (Lines $4 \& 5$ ) parallel and perpendicular to the ice flow. The drilled till samples were combined from $1 \mathrm{~m}$ extracts of the core and weighed up to $7 \mathrm{~kg}$.

\subsection{SAMPLE PROCESSING}

In Pipe 7 only $1 \%$ of $0.25-2.0 \mathrm{~mm}$ fraction indicator grains are $>1.0 \mathrm{~mm}$ in size. To reduce the volume of the till samples they were screened down to $<1.0 \mathrm{~mm}$ grain size before processing. The loss of possible coarse indicators was considered insignificant. The concentration of indicators was based on a GTK modified 3'Knelson Concentrator (Chernet et al. 1999), the final concentrates being liberated through heavy medium separation $\left(\mathrm{d}=3.2 \mathrm{gcm}^{-3}\right)$. The indicator grains $(0.25-1.0 \mathrm{~mm})$ were hand picked under binocular microscope and their identification was confirmed using SEM-EDS. Chemical analysis of the till silt and clay fraction $(<0.063 \mathrm{~mm})$ of the till samples was performed using XRF and ICP-MS methods.

\section{RESULTS}

\subsection{THE INDICATOR FAN}

The enrichment of indicators in the three inner-most sampling sites of Line 2 (Fig. 2) shows that the indicator fan is approximately $200 \mathrm{~m}$ wide at 600-700 $\mathrm{m}$ distance down-ice from Pipe 7, i.e. at the starting point of Line 1. The maximum concentration of indicators (238) is found in a basal sample located 700 $\mathrm{m}$ SE from the kimberlite and slightly off the main ice flow direction. In the other sampling sites on Line 2 the indicator content is considerably lower. The highest concentration on Line 1 is found $1.2 \mathrm{~km}$ exactly downice from the pipe. The results of Line 3 show that at this distance the indicator fan is already approximately 500 $\mathrm{m}$ wide, and as in Line 2 the highest concentration is usually found at the base of the till bed. Further away the indicators are slightly enriched in the uppermost part of the till. This in agreement with the classical observation that the transport distance of a basal till is shorter in its lower parts than in its upper parts (Sauramo 1924, Nurmi 1976, Salminen \& Hartikainen 1985).

\subsection{INDICATORS IN TILL}

Figures $3 \mathrm{~A}$ and $3 \mathrm{~B}$ show the fraction $0.5-1.0 \mathrm{~mm}$ indicator mineral distribution in Pipe 7 and in the till samples. The indicator population in till corresponds in mineralogy almost exactly that of the kimberlite. No significant differences were detected either in the indicator grain size distribution (fractions $0.25-0.5 \mathrm{~mm}$ and $0.5-1.0 \mathrm{~mm}$ ) or their texture. During glacial transport dilution through mixing with material derived from country rock is the dominant process; degradation or physical breakdown of grains does not have a significant effect on the indicator mineral abundance in till (McClenaghan \& Kjarsgaard 2001).

\subsection{CheMicAL ANALYSES}

Chemical analyses using XRF and ICP-MS instruments were performed on selected till samples of variable indicator contents and distances to the kimberlite. The material analysed was the silt and clay fraction $(<0.063$ $\mathrm{mm}$ ). The objective was to study possible geochemical anomalies in the basal till down-ice from Pipe 7 and the correlation between the fine fraction composition and the indicator content of the samples. Special focus was on the combination of incompatible ( $\mathrm{Sr}, \mathrm{Ba}, \mathrm{LREE}, \mathrm{Nb}$, $\mathrm{Ta}, \mathrm{Hf}, \mathrm{Zr}, \mathrm{P}, \mathrm{Ti})$ and compatible elements (Mg, Ni, Cr and $\mathrm{Co}$ ), which together are diagnostic for kimberlitic 
rocks (Fipke et al. 1995). The outcome of this part of the study was negative. All samples were uniform in chemical composition regardless of their location in the study area. The till fine fraction did not reflect the indicator content of the sample.

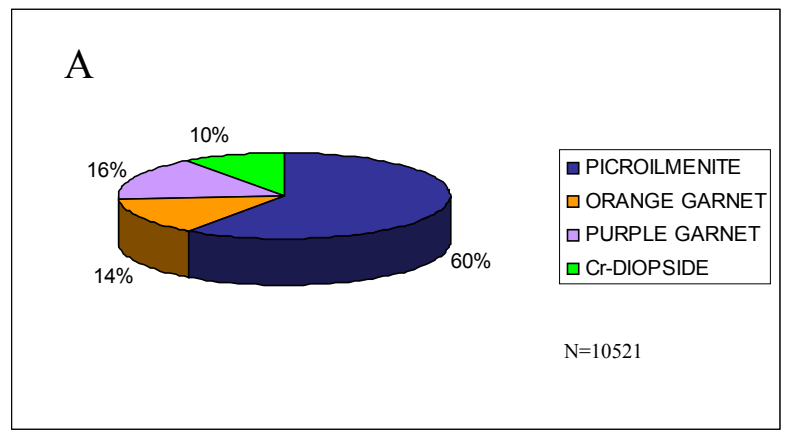

$\mathrm{B}$

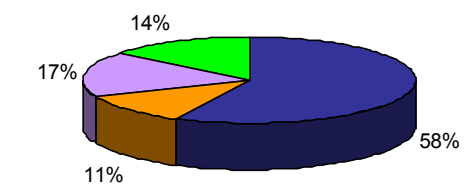

$\square$ PICROILMENITE $\square$ ORANGE GARNET $\square$ PURPLE GARNET $\square$ Cr-DIOPSIDE

$\mathrm{N}=1928$

Figures 3A and 3B: $3 \mathrm{~A}$ shows the mutual proportions of the 0.5-1.0 mm fraction indicators in Pipe 7 and $3 \mathrm{~B}$ shows the corresponding results of the till samples.

\subsection{DRILLINGS}

Another small kimberlitic body was discovered by drilling $300 \mathrm{~m}$ down-ice from Pipe 7, exactly at the intersection of Lines 4 and 5 (Fig. 2). Based on preliminary results the body is very similar to Pipe 7 in mineralogy and most probably a satellite intrusion related to it. The new body as well as Pipe 7 lie in a topographical depressions and are covered by thick icelake clay and till overburden, $>12 \mathrm{~m}$ in total. The drill samples revealed a complex indicator dispersion pattern in the basal till in the vicinity of the lines 4 \& 5 intersection. This probably reflects the two superimposed indicator fans derived from Pipe 7 and the newly discovered body and also the variations in bedrock topography and till bed thickness. However, it seems that the "indicator plume" from Pipe 7 , i.e. basal till enriched in kimberlitic material, stays at the bedrock-till interface as the bedrock topography rises away from the kimberlite subcrop.

\section{CONCLUSIONS}

The transport of indicator minerals in till is a complicated process that is affected by various factors such as the bedrock topography and the till bed thickness (e.g. Hirvas et al. 1977). Till is not entirely homogenous and a "nugget effect" - a large piece of weathered kimberlite or disintegrated megacryst - may result in a high number of indicator grains in a sample. The indicator grains derived from the Lahtojoki kimberlite form a relatively well-defined fan in the basal till that can be followed at least $2 \mathrm{~km}$ down-ice. The maximum concentration of indicators in the main ice flow direction is found $1.2 \mathrm{~km}$ from the kimberlite. At this distance the fan is approximately $500 \mathrm{~m}$ wide, quite symmetrical and the indicator concentration is highest at the base of the till bed. Further away the indicators are slightly enriched in the upper part of the till as the lower part is renewed from material derived from the country rock. The other kimberlitic body located $300 \mathrm{~m}$ down-ice from Pipe 7 complicates somewhat the indicator dispersal pattern in the area i.e. there are in fact two superimposed indicator fans. 3-D modeling of the drill cores as well as the study of the newly discovered kimberlite is in progress. The indicator population in till corresponds to that of the pipe in mineralogy, grain size and texture. No obvious correspondence was found between till fine fraction geochemistry and indicator count of the till samples.

\section{ACKNOWLEDGEMENTS}

This study was conducted at GTK and supported also by the Academy of Finland. The authors would like to thank especially Professor Matti Saarnisto for discussions and useful recommendations. Dr Keijo Nenonen and Ms Leeni Vilpas are appreciated for the data of the previous GTK heavy mineral survey in the Kaavi area in 1994. We are also grateful to Mr Matti Tyni, Mr Ahti Nissinen, Dr Hugh O’Brien and $\mathrm{Mr}$ Pekka Huhta, as well as to the personnel of the GTK Heavy Mineral Laboratory. 


\section{REFERENCES}

Calcagnile G., 1982. The lithosphere-astenosphere system in Fennoscandia. Tectonoph. 90: 19-35.

Chernet T., Marmo J. \& Nissinen A., 1999. Technical Note. Significantly improved recovery of slightly heavy minerals from Quaternary samples using GTK modified 3"Knelson preconcentrator. Min. Eng. 12: 1521-1526.

Dawson J.B. \& Stephens W.E. 1975. Statistical analysis of garnets from kimberlites and associated xenolith. J. Geol. 83: 589-607.

Fipke C.E., Gurney J.J. \& Moore R.O., 1995. Diamond exploration techniques emphasising indicator mineral geochemistry and Canadian examples. Geol. Surv. Canada, Bull. 423, 86 pp.

Gaál G. \& Gorbatschev R., 1987. An outline of the Precambrian evolution of the Baltic Shield. Precambrian Res. 35: 15-25.

Hirvas H., Alftan A., Pulkkinen E., Puranen R. \& Tynni R. 1977. Raportti malminetsintää palvelevasta maaperätutkimuksesta Pohjois-Suomessa vuosina 1972-1976. Summary: A report on glacial drift investigations for ore prospecting purposes in northern Finland 1972-1976. Geol. Surv. of Finland, Rep. Inv. 19, 54 pp.

Hirvas H. \& Nenonen K. 1987. The till stratigraphy of Finland. Geol. Surv. of Finland, Spec. Paper 3, pp. 4963.

Kontinen A., Paavola J., \& Lukkarinen H. 1992. K-Ar ages of hornblende and biotite from Late Archean rocks of eastern Finland; interpretation and discussion of tectonic implications. Geol. Surv. Finland Bull. 365, $31 \mathrm{pp}$.

Korsman K., Koistinen T., Kohonen J., Wennerström M., Ekdahl E., Honkamo M., Idman H. \& Pekkala Y. (eds.) 1997. Suomen kallioperäkartta = Berggrundskarta över Finland $=$ Bedrock map of Finland 1:1 000 000. Geol. Surv. of Finland.

Kukkonen I.T. \& Jõeleht A., 1996. Geothermal modelling of the litosphere in the central Baltic Shield and its southern slope. Tectonoph. 255 (1-2): 25-45.

McClenaghan M.B. \& Kjarsgaard B.A., 2001. Indicator mineral and geochemical methods for diamond exploration in glaciated terrain in Canada. In: M.B. McClenaghan, P.T. Bobrowsky, G.E.M. Hall and S.J. Cook (eds.), Drift Exploration in Glaciated Terrain. Geol. Soc., London, Spec. Publ. 185, pp. 83-123.

Nenonen K. 1995. Pleistocene stratigraphy and reference sections in southern and western Finland. Ph.D. Thesis, Geol. Surv. of Finland, Kuopio, 205 pp.

Nurmi A. 1976. Geochemistry of the till blanket at the Talluskanava $\mathrm{Ni}-\mathrm{Cu}$ ore deposit, Tervo, Central Finland. Geol. Surv. of Finland, Rep. Inv. 15, 84 pp.

O’Brien H.E. \& Tyni M. 1999. Mineralogy and Geochemistry of Kimberlites and Related Rocks from Finland. In: J.J. Gurney, J.L. Gurney, M.D. Pascoe and S.H.Richardson (eds.), Proceedings of the 7th International Kimberlite Conference, pp. 625-636.
Peltonen P. 1999. Silicification of garnet peridotite xenoliths from the Lahtojoki kimberlite pipe, Finland. In: J.J. Gurney, J.L. Gurney, M.D. Pascoe and S.H. Richardson (eds.), Proceedings of the 7th International Kimberlite Conference, pp. 659-663.

Salminen R. \& Hartikainen A. 1985. Glacial transport of till and its influence on interpretation of geochemical results in North Karelia, Finland. Geol. Surv. of Finland, Bull. 335, 48 pp.

Sauramo M. 1924. Tracing of glacial boulders and its application in prospecting. Bull. comm. géol. Finland $67,37 \mathrm{pp}$.

Tyni M., 1997. Diamond prospecting in Finland - a review. In: Papunen H. (edit.), Mineral Deposits: Research and Exploration, Where do They Meet? Proceedings of the 4th SGA Meeting, pp.789-791.

Contact: ML Lehtonen, PO Box 96, FIN-02151 Espoo,

Finland, E-mail: marja.lehtonen@gsf.fi 